Sains Malaysiana 50(3)(2021): 677-689

http://dx.doi.org/10.17576/jsm-2021-5003-10

\title{
Efficacy of Different Solvent for Oleoresin Extraction and Physicochemical Properties of White Pepper Produced Via Water Retting
}

(Keberkesanan Pelarut Berbeza untuk Pengekstrakan Oleoresin dan Pencirian Fizikokimia Lada Putih yang Terhasil Melalui Pengeretan Air)

\author{
Nurul Shahirah AzIZ, Noor-Soffalina Sofian-SEng \& WAN Aida WAN Mustapha*
}

\section{ABSTRACT}

Initially, four different solvents were compared to determine the best solvent for white pepper oleoresin extraction. Methanol was chosen as it resulted in the highest yield and total phenolic content (TPC) of oleoresin extract from white pepper. This study was also carried out to determine the functional and physicochemical properties of white pepper produced via water retting. Fresh pepper berries were soaked in distilled water $(1: 2, w / w)$ at four different temperatures of $28,35,42$, and $49^{\circ} \mathrm{C}$ for 16 days. The yield, oleoresin content, colour, fracturability, free radical scavenging activity, and TPC of white pepper produced were determined on the $4^{\text {th }}, 8^{\text {th }}, 12^{\text {th }}$, and $16^{\text {th }}$ day of the retting process. Results showed that 8 days of retting at $28^{\circ} \mathrm{C}$ was sufficient to produce a significantly $(p<0.05)$ high yield and most fractured white pepper. For other properties, it was suggested that retting time of 8 days was sufficient to produce satisfactory whiteness value, piperine content, free radical scavenging activity, and TPC. Therefore, it can be concluded that the quality of white pepper very much depended on retting temperature compared to the duration of the retting process.

Keywords: Oleoresin extraction; phenolic content; physicochemical; water retting; white pepper

\section{ABSTRAK}

Kajian awal melibatkan perbandingan empat pelarut berbeza untuk menentukan pelarut terbaik bagi pengekstrakan oleoresin lada putih. Metanol telah dipilih kerana memberikan hasil dan jumlah kandungan fenolik (TPC) tertinggi daripada ekstrak oleoresin lada putih. Kajian ini juga dijalankan untuk menentukan ciri-ciri berfungsi dan fizikokimia lada putih yang dihasilkan melalui pengeretan air. Beri lada segar direndam dalam air suling (1: 2, w/w) pada empat suhu berbeza iaitu $28,35,42$ dan $49{ }^{\circ} \mathrm{C}$ selama 16 hari. Jumlah hasil, kandungan oleoresin, warna, kebolehretakan, aktiviti perencatan radikal bebas dan TPC lada putih yang dihasilkan ditentukan pada hari ke-4, ke8 , ke-12 dan ke-16 proses pengeretan. Hasil menunjukkan bahawa pengeretan selama 8 hari pada suhu $28{ }^{\circ} \mathrm{C}$ adalah mencukupi untuk menghasilkan jumlah hasil lada putih dan kebolehretakan yang tinggi $(p<0.05)$. Bagi ciri-ciri lain, dicadangkan bahawa tempoh masa lapan hari pengeretan adalah mencukupi untuk menghasilkan nilai kecerahan, kandungan piperina, aktiviti perencatan radikal bebas dan TPC yang memuaskan. Oleh itu, dapat disimpulkan bahawa kualiti lada putih adalah sangat bergantung kepada suhu berbanding dengan tempoh masa proses pengeretan.

Kata kunci: Fizikokimia; kandungan fenolik; lada putih; pengekstrakan oleoresin; pengeretan air

\section{INTRODUCTION}

Water retting is a traditional practice that has been widely used worldwide to produce white pepper. During the water retting technique, ripe berries of pepper (Piper nigrum L.) are immersed for up to two weeks in flowing water such as the river or in static water tanks to allow the decaying of the outer layer of the pepper pericarp (Nair
2011; Tainter \& Grenis 2001). During this soaking period, the pepper pericarp begins to decay slowly. The naturally existing microorganisms in the water help to loosen and degrade the pericarp skin from the core (Vinod et al. 2014). After sufficient retting, pepper berries are threshed to remove the outer skin and finally sun dried (Paulus 2009). Water retting usually recovers about $25 \%$ or $25-28$ $\mathrm{kg}$ of white pepper from $100 \mathrm{~kg}$ retted ripe berries, with an 
average loss of 8-9 $\mathrm{kg}$ during the production process (Aziz et al. 2019). Besides water retting, dried pepper berries or black pepper can also be used to produce white pepper (Sons et al. 2007). White pepper has been reported to be used in various food, added in meats, seafood, snacks, and in vegetable preparations (Attokaran 2011). The quality of white pepper is often characterised by its functional and physicochemical properties (Vinod et al. 2014). Therefore, it is essential to study these properties to determine the quality of white pepper.

Oleoresin, piperine, and essential oil are the major constituents that are responsible for the peppery sensation of white and black pepper (Tainter \& Grenis 2001). Piperine is a major bioactive component of pepper, characterised by nitrogen-containing compound contributing to the pungency of pepper (Ravindran \& Kallupurackal 2001) and can be sensitive to light and oxygen (Shaikh et al. 2006). The concentration of piperine in the Piperaceae family can be varied; for example, it has been reported to constitute about 2.0 and $7.4 \%$ in black pepper and white pepper, respectively, while in some reports the piperine content was found to be much higher in black pepper at up to $9.0 \%$ (Parthasarathy et al. 2008; Peter 2006; Ravindran 2003). Overall, the value of pepper depends on its pungency and flavour, which is commonly attributed by the presence of piperine alkaloid as well as oleoresin and essential oils (Gorgani et al. 2017). These beneficial compounds can be extracted using the selected method and solvent.

Various techniques and solvent extractions have been conducted on pepper to obtain its valuable chemical constituents such as oleoresins, piperine, as well as essential and volatile oils. These constituents have been widely reported to be beneficial not only as a flavouring agent but also as a food supplement and in pharmaceutical (Shanmugapriya et al. 2012) due to the medicinal and preservative properties (Meghwal \& Goswami 2013; Zarai et al. 2013). Due to the bioactive compound present, pepper is found to exhibit numerous health and therapeutic effects to humans in both traditional and modern practices (Meghwal \& Goswami 2013; Ravindran \& Kallupurackal 2001).

In the determination of good solvents for extraction, a solvent with a high extraction rate and good reproducibility should be chosen (Qi et al. 2014). The solubility of compounds in solvents can vary considerably. For instance, a more polar compound such as phytosteryl glycosides is greatly soluble in polar solvents (Dutta 2003). In terms of sample preparation, a homogenous and high surface area of the sample is able to enhance the extraction efficiency. Dry sample must be ground into a fine size and sieved to get a homogenous size to enhance extraction reproducibility (Mothersill \& Austin
2003). The nature of the sample also plays a significant role in extraction. It is relatively easy to liberate most phytosterols from oil grains and nuts through solvent extraction compared to hard cell walls or from complex polysaccharide-protein matrices in wet vegetable tissues and cereals (Dutta 2003).

Among the different extraction techniques that have been previously reported are subcritical water extraction (Hassas Roudsari 2007), continuous subcritical water extraction (Gámiz-Gracia \& Luque de Castro 2000; Jiménez-Carmona, et al. 1999; Soto Ayala \& Luque de Castro 2001), classic solvent extraction (Shaikh et al. 2006; Shingate et al. 2013; Zarai et al. 2013), supercritical fluid extraction (Hamrapurkar et al. 2011; Lenucci et al. 2015), and hydrotropes extraction (Shingate et al. 2013). Other studies mentioned that the conventional Soxhlet method yields the best overall results among five different extraction procedures (Prytula \& Pavolostathis 1996). Therefore, Soxhlet extraction using dry and ground sediment is recommended in this study.

It is known that different types of extractants provide different responses and ability to extract bioactive compounds present in the food sample. Previous works have shown that pepper can be extracted repeatedly with organic solvents such as acetone, ethanol, or chlorinated hydrocarbons (Marion 1960), dichloromethane (Raman \& Gaikar 2002), petroleum ether and chloroform (Kolhe et al. 2011), a mixture of solvents such as n-hexane, ethyl acetate, and glacial acetic acid (Hamrapurkar et al. 2011), as well as ethanol and water (Santamaría et al. 2000). The findings from these studies vary differently as the solvents have different effects thus, yielding different results. This study was conducted to determine the antioxidant potential as well as the total phenolic content of commercial white pepper extracted using four different solvents, namely n-hexane, dichloromethane, methanol, and ethanol. Each of the solvents was chosen due to the different polarity and ability to extract active compounds from the sample.

\section{MATERIALS AND METHODS}

\section{PRE-DETERMINATION SOLVENT FOR WHITE PEPPER} EXTRACTION

Five gram of white pepper powder (Peace Brand, Chiapheng Chng Sdn Bhd) was purchased from local supermarket Jaya Grocer, Bangi and was treated with four different solvents $(200 \mathrm{~mL})$ namely $\mathrm{n}$-hexane, dichloromethane, methanol, and ethanol (analytical grade, Merck Sdn Bhd) for three hours. All extracts were then subjected to the determination of oleoresin, DPPH activity and TPC for comparison to choose the best solvent prior to extract the white pepper from water retting. 


\section{DETERMINATION OF OLEORESIN YIELD OF WHITE} PEPPER FROM WATER RETTING

Five grams of fine ground white pepper powder was sieved and subjected to controlled Soxhlet extraction. Each extraction used $200 \mathrm{~mL}$ of methanol and extracted for $3 \mathrm{~h}$. The extracted methanol was collected in empty round bottom flask, $\mathrm{W}_{\mathrm{i}}(\mathrm{g})$ and then removed using rotatory evaporator consistently for $24-25 \mathrm{~min}$ at $60 \mathrm{rpm}$ on $50{ }^{\circ} \mathrm{C}$ until thick and green liquid was obtained. The mass of flask after solvent removal $\mathrm{W}_{\mathrm{f}}(\mathrm{g})$ deduce $\mathrm{W}_{\mathrm{i}}(\mathrm{g})$ and recorded as mass of oleoresin extracted $\mathrm{W}_{\mathrm{o}}(\mathrm{g})$. The extracted yield was recorded (\%) and stored at a chill temperature below $4{ }^{\circ} \mathrm{C}$.

DETERMINATION OF FUNCTIONAL AND PHYSICOCHEMICAL PROPERTIES OF WHITE PEPPER PRODUCED BY WATER RETTING PROXIMATE ANALYSIS OF FRESH PEPPER BERRIES

Three batches of pepper berries were analysed to determine the ash content, moisture, total protein, total fat, crude fibre, and total carbohydrates. All sample were done in quadruplicate $(n=4)$ using the AOAC (1975) analytical method.

\section{WATER RETTING PROCESS}

Fresh pepper berries were obtained from Herba Bagus farm in Kluang, Johor. Fresh pepper was immersed in water with a 1:2 ratio (pepper berries:water, w/w) (Aziz et al. 2018). All flasks $(n=3)$ were then placed in a temperature-controlled Orbital water bath shaker (Gyromax 929) at temperature of $28,35,42$, and $49^{\circ} \mathrm{C}$ for $4,8,12$ and 16 days. The temperature of the water bath was monitored regularly using a thermometer. Retting water was changed daily to avoid bacterial contamination and to mimic the conventional retting method.

\section{DETERMINATION OF YIELD}

White pepper yield obtained after the retting process was air dried for a day and dried in an oven for $5 \mathrm{~h}$ at $60^{\circ} \mathrm{C}$. The weight of white pepper after oven drying was recorded as the final yield.

\section{DETERMINATION OF WHITENESS}

White pepper seed was ground into fine powder to assess the colour of the pepper produced. Colour was measured using a Minolta colourimeter (Chromameter CR 400, Japan) with a Hunter Lab colour system $\left(\mathrm{L}^{*}, \mathrm{a}\right.$ *, and b *). The whiteness value was calculated using the Color iMatch Color Calculations Guide formula, WIhunter = L - 3b.

\section{DETERMINATION OF FRACTURABILITY}

The fracturability test of white pepper was carried out using Shimadzu Twin-Column Texture Analyzer $500 \mathrm{~N}$ (AGS-Japan). White pepper seeds $(n=3)$ within the size range of 4.0-4.2 $\mathrm{mm}$ were compressed using a $20 \mathrm{~mm}$ diameter cylindrical probe at a rate of $25 \mathrm{~mm} \mathrm{~min}^{-1}$ and load of $0.5 \mathrm{kN}$. The value of force $(\mathrm{N})$ required to break the white pepper seed was recorded.

\section{DETERMINATION OF PIPERINE CONTENT}

White pepper was extracted for $3 \mathrm{~h}$ with $95 \%$ methanol using the Soxhlet extraction technique. The liquid extract was diluted $1000 \mathrm{x}$, and $20.00 \mu \mathrm{L}$ of the diluent was injected into High-Performance Liquid Chromatography (HPLC) equipped with Photodiode Array Detector (PDA). The column used was Water XBridge $(\mathrm{C} 184.6 \times 150 \mathrm{~mm}$, $4.5 \mu \mathrm{m})$ with a flow rate of $1 \mathrm{~mL} \mathrm{~min}^{-1}$ and mobile phase of methanol:deionized water (2.3:1). Piperine analytical standard (Sigma Aldrich) of 1, 2, 4, 6, 8, and 10 ppm were prepared as a reference.

\section{DETERMINATION OF RADICAL SCAVENGING ACTIVITY (DPPH)}

A diluted volume of $1 \mathrm{~mL}$ sample $(0.5 \mathrm{mg} / \mathrm{mL})$ was added to $2.9 \mathrm{~mL}$ methanolic DPPH solution $(0.15 \mathrm{mM})$ in the test tube. After storing for $30 \mathrm{~min}$ in the dark, $200 \mu \mathrm{L}$ of mixture reaction was pipetted into 96 well plates and measured at $517 \mathrm{~nm}$ by using a microplate spectrophotometer (BioTek Epoch). The percentage of radical activity was measured according to (1).

$\%$ Free radical scavenging activity $=(100[\mathrm{Ab} 1-\mathrm{As} 2]) / \mathrm{Ab} 1(1)$

where Ab1 was the absorbance of DPPH blank and As2 was the absorbance of sample. Ascorbic acid standard calibration was prepared for $0,10,20,30,40$, and $50 \mathrm{ppm}$.

\section{DETERMINATION OF TOTAL PHENOLIC CONTENT (TPC)}

Phenolic content of white pepper was measured using the Folin-Ciocalteu method. Sample extract of $100 \mu \mathrm{L}(0.5$ $\mathrm{mg} / \mathrm{mL}$ ) was added to $5 \mathrm{~mL}$ of Folin-Ciocalteu reagent (1:10) and $4 \mathrm{~mL}$ solution of $7.5 \% \mathrm{Na}_{2} \mathrm{CO}_{3}$. The mixture was then stored in the dark for $90 \mathrm{~min}$. Afterwards, $200 \mu \mathrm{L}$ of the mixture was pipetted into 96 well plates and measured at $760 \mathrm{~nm}$ absorbance by the microplate spectrophotometer BioTek Epoch. A standard curve Gallic acid was prepared at a concentration of 1-100 ppm and phenolic activity was determined for per $\mathrm{g}$ sample (mg $\mathrm{GAE} / \mathrm{g}$ ). 


\section{STATISTICAL ANALYSIS}

All the measurements were carried out in triplicates, and the values obtained were expressed as mean \pm standard deviation (SD). The data obtained from the experiments were subjected to the two-way analysis of variance (ANOVA) followed by the Duncan test to determine the means and significant difference. IBM Statistical Package for the Social Sciences (Version 22) software was used for conducting the statistical analysis.

\section{RESULTS AND DisCUSSION}

\section{EFFICACY OF DIFFERENT SOLVENT FOR EXTRACTION OF} WHITE PEPPER OLEORESIN

From the study, there is significant different $(p<0.05)$ for the extracted yield obtained using different solvents (Table 1$)$. The most significantly $(p<0.05)$ highest yield was obtained by methanolic extracts at $13.89 \pm 1.28 \%$ and the lowest was by acetic acid at $3.84 \pm 3.30 \%$. The extracted yield collected from solvent extraction from white pepper powder is the oleoresin as mentioned in many references (Borges \& Pino 1993; Premi 2000; Ravindran \& Kallupurackal 2012). Oleoresin is the thick and greenish liquid extract mainly composed of oils, resin, piperine, and volatile oils (Srinivasan 2007). With respect to hygienic considerations, spice oils and oleoresins prove to be a suitable alternative for food flavouring (Schweiggert et al. 2007). Besides white pepper, oleoresin can also be found in other types of plants such as cardamom, ginger, turmeric, and garlic.

From the study, a significant difference $(p<0.05)$ was observed for the oleoresin yield obtained using different solvents. Table 1 shows the most significant highest ( $p<$ 0.05 ) yield was obtained by methanolic extracts at 13.89 $\pm 1.28 \%$ and the lowest was by acetic acid at $3.84 \pm$ $3.30 \%$. Acetic acid extracted yield was not significantly different $(p>0.05)$ from $n$-hexane and ethanol. Oleoresin in pepper has been reported to be extractable using dipolar aprotic solvents (acetone and ethyl acetate), halogenated solvent (ethylene dichloride), and polar protic solvent (ethanol) (Balasubramanian et al. 2016; Ravindran \& Kallupurackal 2001).

Report stated that yields of extractable oleoresin were in the range of $5-15 \%$ showing methanol $(13 \%)$ is a great solvent to extract oleoresins in white pepper due to its high extraction yield while n-hexane and acetic acid are the opposite. This may be due to the higher polarity of methanol that enables it to give a better yield extract. Polar lipids such as phospholipid may be contained in the oleoresin extract as it dissolves easily in methanol. Meanwhile, lipids such as triacylglycerides or sterol esters with a functional group of low polarity are soluble in non-polar hydrocarbon solvents like hexene (Meullemiestre 2015). From the study, the low polarity solvent (e.g. hexane) results in a lower oleoresin yield, but it shows the amount of non-polar lipid extractable from the sample. However, the concentration in the extract may be reduced if a non-polar solvent is used because methanol dissolves a larger portion of polar compounds.

As shown in Table 1, all extracts from different solvents resulted in significantly different $(p<0.05)$ free radical scavenging activities. The results showed that each solvent has a different ability to extract the component that exhibits the free radical scavenging capability. The lowest activity was recorded with acetic acid extract at $42.95 \pm 1.52 \%$, followed by $n$-hexane at $51.89 \pm 0.09 \%$, methanol at $83.16 \pm 0.38 \%$, and the highest was ethanol at $87.51 \pm 0.38 \%$ (Borges \& Pino 1993; Kanaki et al. 2008; Sadasivam \& Manickam 1992; Sruthi et al. 2013). This shows that ethanol is a great solvent to extract antioxidant compounds from white pepper powder, followed by methanol, n-hexane, and lastly acetic acid. Many researchers have previously used ethanol to extract the chemical content of pepper oleoresin.

Oleoresin in white pepper may be the compound that contributes to the DPPH activity and TPC. However, the solubility of oleoresin in each solvent seems to be different, hence giving the different results of DPPH activity. Misharina et al. (2009) demonstrated a significant influence of the concentration of white pepper essential oils on their antioxidant properties. Singh et al. (2013) stated that piperine, flavonol glycosides, and phenolic amides are responsible for the antioxidant activity of oleoresins. Piperine in oleoresins extracted using an organic solvent such as ethanol is able to exhibit an antioxidant effect (Choi et al. 2007; Upadhyay et al. 2013).

Zarai et al. (2013) stated that piperic acid, the base-hydrolysis of the alkaloid piperine, is able to give a higher radical scavenging effect due to the presence of the $-\mathrm{COOH}$ radical after the transformation of piperine into piperic acid. Other than that, Steinhaus and Schieberle (2005) reported that a-pinene, linalool, b-damascenone, eugenol, skatole, m-cresol, guaiacol, and piperonal are among the main chemical constituents with antioxidant capacity in white pepper. Piperine compound has different solubility in different solvents; as shown in the work of Shingate et al. (2013), ethanol, dichloromethane, and glacial acetic acid gave 3.2, 5.0, and 4.6\% yield of piperine, respectively. Piperine is generally soluble in petroleum ether, chloroform, ethanol, and methanol but has poor solubility in water (Kolhe et al. 2011). Because of the different degree of solubility of piperine in different polarities of solvent, some studies have worked on optimising the solvent extraction and the use of a mixture solvent such as n-hexane: ethyl acetate: glacial acetic 
acid (3:1:0.1) in HPTLC (Hamrapurkar et al. 2011) and double by-pass Soxhlet extraction by using methanol (Subramanian et al. 2016).

TPC was conducted to determine the polyphenols of the sample. Plant polyphenols are found to be an effective oxygen scavenger, reducing agent, and hydrogen atom donator (Karaman et al. 2010; Nurhanan et al. 2012). According to Hatami et al. (2014), plant phenolics are able to function as primary antioxidants or free radical scavengers. There is a significantly different $(p<0.05)$ effect of different solvents on the TPC, in which methanol gave significantly $(p<0.05)$ the highest TPC compared to the other solvents with $49.96 \pm 4.73 \mathrm{mg} \mathrm{GAE} / \mathrm{g}$ (Table 1). This indicates that methanol solvent is able to extract more yield as well as phenolic content of white pepper whilst acetic acid solvent extract has the lowest results on TPC. This is similar to Butsat and Siriamornpun (2016), where the treatment of Amomum chinense leaves with $80 \%$ methanol for $12 \mathrm{~h}$ gave a higher amount of phenolics and antioxidant activity compared to the other conditions tested.
This shows that the most appropriate solvent to give a high percentage of free radical scavenging activity is ethanol whilst methanol is best used to obtain a high total phenolic content from white pepper. The high free radical scavenging activity exhibited by the results may also be contributed by $\alpha$-tocopherol and polyphenol contents (Ravindran \& Kallupurackal 2001) and also the alkaloid piperine present in white pepper (Andrade \& Ferreira 2013; Upadhyay et al. 2013). This polyphenol content subsequently gives the effect of high antioxidant activity in white pepper but often lower than in black pepper (Agbor et al. 2006). Table 2 shows the correlation between oleoresin yield, TPC and antioxidant. It can be observed that there is a positive and significant $(p<0.05)$ correlation between the three variables. Similar results of a highly positive correlation between TPC and antioxidant activity has been reported in various plant species and plant-based food products (Esmaeili et al. 2016; Wern et al. 2016). This study chooses methanol as the solvent for extracting the sample as it is able to give a significantly high extraction yield and extract the active phenolic compound from white pepper.

TABLE 1. Effect of different extraction solvent on the oleoresin yield, DPPH, and TPC

\begin{tabular}{lcccc}
\hline \multicolumn{1}{c}{ Types of solvent } & Polarity Index & Oleoresin & DPPH activity (\%) & $\begin{array}{c}\text { TPC } \\
(\mathrm{mg} \mathrm{GAE} / \mathrm{g})\end{array}$ \\
\hline Acetic acid & 6.0 & $3.84 \pm 3.30^{\mathrm{b}}$ & $42.95 \pm 1.52^{\mathrm{d}}$ & $19.56^{\mathrm{d}} \pm 0.37^{\mathrm{c}}$ \\
Methanol & 5.1 & $13.89 \pm 1.28^{\mathrm{a}}$ & $83.16 \pm 0.38^{\mathrm{b}}$ & $49.96 \pm 4.73^{\mathrm{a}}$ \\
Ethanol & 4.3 & $7.75 \pm 1.07^{\mathrm{b}}$ & $87.51 \pm 0.38^{\mathrm{a}}$ & $42.97 \pm 6.14^{\mathrm{ab}}$ \\
N-hexane & 0.1 & $4.28 \pm 0.36^{\mathrm{b}}$ & $51.89 \pm 0.10^{\mathrm{c}}$ & $33.19 \pm 6.09^{\mathrm{bc}}$ \\
\hline
\end{tabular}

*As stated in Lough and Wainer (1995)

TABLE 2. Correlation between oleoresin yield, TPC, and antioxidant

\begin{tabular}{|c|c|c|c|c|}
\hline & Factor & Oleoresin & TPC & Antioxidant \\
\hline \multirow[t]{3}{*}{ Oleoresin } & Pearson Correlation & 1 & $0.771^{*}$ & $0.760^{*}$ \\
\hline & Sig. (2-tailed) & & 0.025 & 0.029 \\
\hline & $\mathrm{N}$ & 8 & 8 & 8 \\
\hline \multirow[t]{3}{*}{$\mathrm{TPC}$} & Pearson Correlation & $0.771^{*}$ & 1 & $0.875^{* *}$ \\
\hline & Sig. (2-tailed) & 0.025 & & 0.004 \\
\hline & $\mathrm{N}$ & 8 & 8 & 8 \\
\hline \multirow[t]{3}{*}{ Antioxidant } & Pearson Correlation & $0.760^{*}$ & $0.875^{* *}$ & 1 \\
\hline & Sig. (2-tailed) & 0.029 & 0.004 & \\
\hline & $\mathrm{N}$ & 8 & 8 & 8 \\
\hline
\end{tabular}

*significant at $p<0.05 *$ significant at $p<0.01$ 


\section{PROXIMATE ANALYSIS OF FRESH PEPPER BERRIES}

Many studies have shown the proximates of white pepper and black pepper but they are lacking on fresh pepper berries. From Figure 1, it can be seen that pepper berries have high moisture content $(67.26 \%)$, followed by total carbohydrate $(17.44 \%)$, crude fibre $(8.75 \%)$, total fat $(4.4 \%)$, ash $(1.43 \%)$, and total protein $(0.72 \%)$. Dry recovery percentage varies among cultivars and growing conditions, but usually, the recovery range is $28-38 \%$ for black pepper (Ravindran \& Kallupurackal 2012) and 20$25 \%$ for white pepper (Paulus 2009). This indicates more than half of the mass of pepper berries belongs to the nonrecovery matters mainly from their disposed skin and flesh. It has been reported that the proportion of starch increases as the berries reach maturity for green pepper. From the age of 4.0 to 5.5 months, the starch content of green pepper can range from 15.66 to $46.62 \%$ according to respective cultivars (Ravindran \& Kallupurackal 2001). Ravindran (2003) found that the bulk density has a positive correlation with the starch of black pepper. A positive correlation was also observed between crude fibre and essential oil, crude fibre and total fat, and essential oil and total fat. Total fat $(4.4 \%)$ obtained from pepper berries may represent the oleoresin and essential oils content in pepper berries. Crude fibre found in pepper berries was $8.75 \%$. Fibres from different sources of the plant contain different amounts of cellulose, hemicellulose and lignin. The lignocellulosic material in the plant fibres degrades during storage, but the ash content containing inorganic materials increases with storage period (Ramawat \& Ahuja 2016). Ash provides a measure of inorganic minerals in pepper berries which is $1.43 \%$. Plant leaves commonly have a higher ash content compared to other parts of the plant (Goss 2013). The total protein content from this study was found lower at $0.72 \%$ probably due to the young pepper berries used, as protein is usually higher in mature seeds or plants. Samaj and Thelen (2007) stated that plant cells generally contain low amounts of protein protected by the cell walls; hence, the extraction of protein from plant samples is a bit challenging and requires extreme measures.

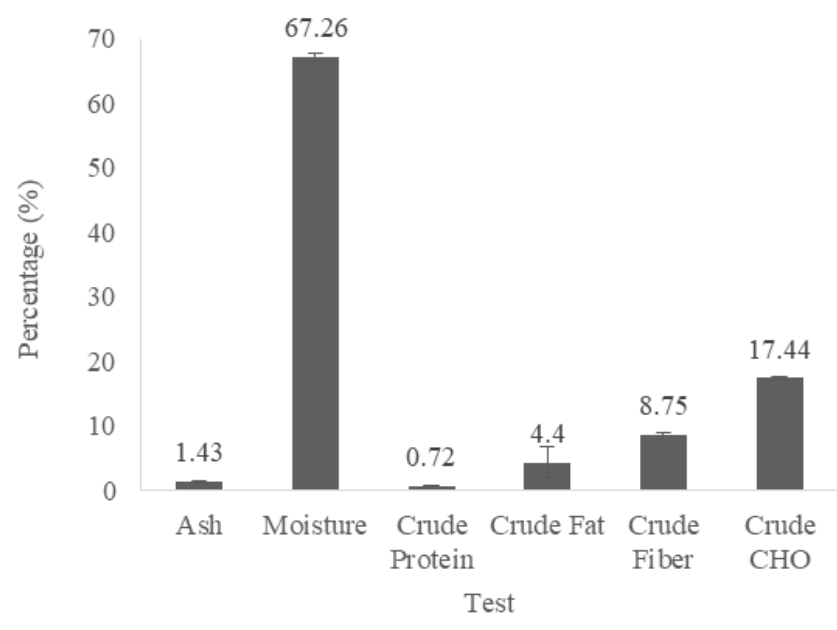

FIGURE 1. Proximate analysis of fresh pepper berries

\section{PHYSICOCHEMICAL PROPERTIES OF WHITE PEPPER} PRODUCED VIA WATER RETTING WHITE PEPPER YIELD

Figure 2 shows the white pepper yield produced after the water retting process at different temperatures and days. It can be observed that the retting temperature of $28^{\circ} \mathrm{C}$ produced a significantly higher yield by mass $(p<0.05)$ compared to other retting temperatures tested. The highest yield $(19.19 \pm 4.35 \%)$ was obtained after 12 days of water retting at $28{ }^{\circ} \mathrm{C}$ but was not significantly different from the yield retted on day 8 at $28^{\circ} \mathrm{C}$. Other previous works have reported variations in the maximum number of days ranging from 9 to 15 days for the soaking of pepper berries (Ibrahim et al. 2014). According to Paulus (2009), after 10 days of retting, the recovery rate for white pepper is about 
$20-25 \%$ of the weight of mature berries. In comparison, this study shows that it is sufficient to ret the pepper berries for only 8 days at $28{ }^{\circ} \mathrm{C}(19.02 \pm 3.48 \%)$ to produce a significant yield. Retting conducted in natural water sources such as the river and pond may be subjected to inconsistent temperatures according to the weather. Thus, it may require a longer time to ret the pepper berries fully. The presence of microorganisms at optimum temperature is able to produce sufficient enzymes that can breakdown the cell wall of the pepper thus aiding the decortication process (Akin 2010; Tahir et al. 2011). The lowest yield obtained was $2.11 \pm 0.94 \%$ on the 4 th day at $42{ }^{\circ} \mathrm{C}$. Yields from all other temperatures tested $\left(35,42\right.$ and $\left.49{ }^{\circ} \mathrm{C}\right)$ regardless of the number of retting days had no significant difference $(p>0.05)$ between each other suggesting that a temperature higher than $28^{\circ} \mathrm{C}$ is not favourable for pepper berries decortication.

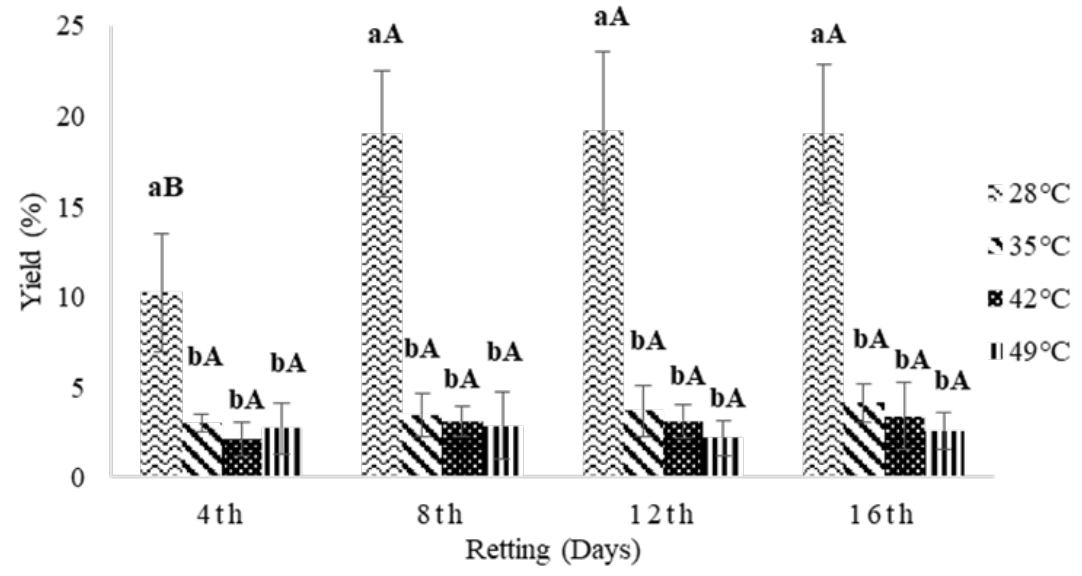

FIGURE 2. Yields of white pepper produced after the water retting process at different temperatures and days. ${ }^{\mathrm{a}-\mathrm{b}}$ Means \pm standard error with different retting temperatures are significantly different $(p<0.05)$. ${ }^{\mathrm{A}-\mathrm{B}}$ Means \pm standard error with different retting times are significantly different $(p<0.05)$

WHITENESS OF WHITE PEPPER

According to Zachariah (2008), a bright creamy white colour is one of the properties that contribute to the high value and acceptance of white pepper produced. It was observed that prolonged immersion in low temperature $\left(28{ }^{\circ} \mathrm{C}\right)$ particularly after 12 to 16 days lowered the whiteness of white pepper. Figure 3 shows that retting at $42{ }^{\circ} \mathrm{C}$ and after 8 days gave a significantly $(p<0.05)$ high whiteness level of $31.17 \pm 0.91$. Meanwhile, a lower whiteness level of $27.25 \pm 1.22$ and $27.27 \pm 1.55$ was obtained at $28{ }^{\circ} \mathrm{C}$ after 12 and 16 days, respectively.

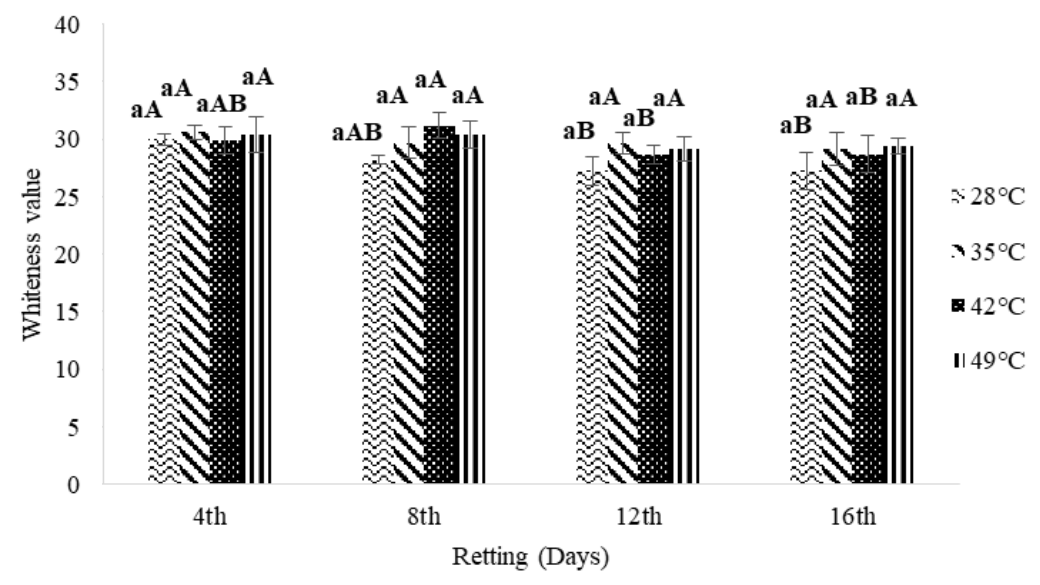

FIGURE 3. Whiteness of ground white pepper produced after the water retting process at different temperatures and days. ${ }^{\mathrm{a}-\mathrm{b}}$ Means \pm standard error with different retting temperatures are significantly different $(p<0.05)$. ${ }^{\mathrm{A}-\mathrm{B}}$ Means \pm standard error with different retting times are significantly different $(p<0.05)$ 


\section{FRACTURABILITY OF WHITE PEPPER}

Figure 4 shows the fracturability of white pepper produced. The result shows that a lower retting temperature at $28{ }^{\circ} \mathrm{C}$ recorded a significantly $(p<0.05)$ lower mean force compared to other temperatures (at the same day) showing the ease of breaking the white pepper produced. A low force was obtained at $28{ }^{\circ} \mathrm{C}$ on day 4 followed by day 8 , and the lowest is on day 16 with 22.67 $\pm 0.19 \mathrm{~N}$ for the same temperature $\left(28^{\circ} \mathrm{C}\right)$. The longer time and low temperature of retting seem to allow more uptake of water that would soften the pericarp and also the internal seed. This result was also reported by Rosnah and Chan (2014), describing the efficiency of the retting process was very much influenced by the uptake of water into the pericarp during the soaking period that softened the pericarp. Their findings show that at the fifteenth soaking day, the fracture force becomes constant at $21.89 \mathrm{~N}$ for 10 samples tested. The lower force to crack white peppercorn can help to ease milling process to get pepper powder.

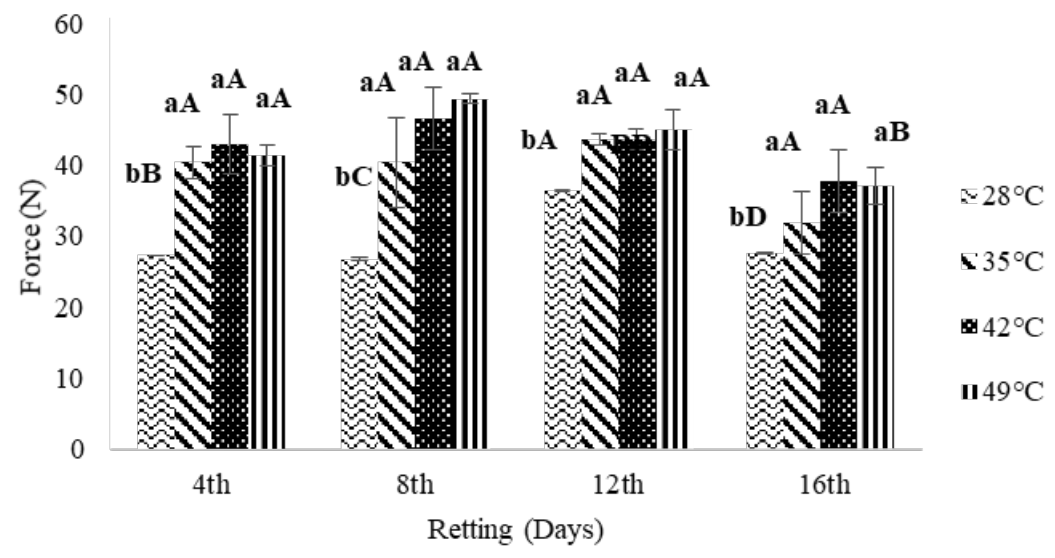

FIGURE 4. Fracturability of white pepper produced after water retting process at different temperature and days. ${ }^{\mathrm{a}-\mathrm{b}}$ Means \pm standard error with different retting temperature are significantly different $(p<0.05)$. ${ }^{\mathrm{A}-\mathrm{B}}$ Means \pm standard error with different retting time are significantly different $(p<0.05)$

FUNCTIONAL PROPERTIES OF WHITE PEPPER PRODUCED VIA WATER RETTING FREE RADICAL SCAVENGING ACTIVITY OF WHITE PEPPER

Table 3 shows that at $28{ }^{\circ} \mathrm{C}$, the free radical scavenging activity of white pepper is significantly lower $(p<0.05)$ compared to all other temperatures $(35,42$, and 49 $\left.{ }^{\circ} \mathrm{C}\right)$. High antioxidant properties of white pepper were observed at a higher temperature of $35^{\circ} \mathrm{C}$ on day 8 with $92.09 \pm 0.19 \%$ while a lower temperature of $28^{\circ} \mathrm{C}$ and day 4 produced the lowest antioxidant properties with 85.07 $\pm 5.60 \%$. Agbor et al. (2006) reported lower concentrations of the non-hydrolysed extract of white pepper had significantly higher $(p<0.001)$ DPPH radical scavenging compared to the non-hydrolysed extract of black pepper. The study suggests that the principal components in white pepper belong to the phenolic compounds that exhibit antioxidant activity.

The antioxidant activity in pepper is attributed by the tocopherol and polyphenol contents in it (Andrade \& Ferreira 2013). The result of DPPH is consistent with the total phenolic content (TPC) in which 35,42 , and $49{ }^{\circ} \mathrm{C}$ resulted in higher TPC compared to retting at $28^{\circ} \mathrm{C}$. Besides the polyphenol compound, Zarai et al. (2013) also stated that piperic acid is able to give a higher radical scavenging activity than piperine. At a final concentration of 50 $\mathrm{mg} / \mathrm{mL}$, the percentage of radical scavenging activity of piperine and piperic acid was $10.28 \%$ and $29.5 \%$, respectively. The scavenging activity after transformation of piperine into piperic acid can be related to the presence of the $-\mathrm{COOH}$ radical. 
TABLE 3. Free radical scavenging activity (\%) of white pepper produced after the water retting process at different temperatures and days

\begin{tabular}{|c|c|c|c|c|}
\hline & $28^{\circ} \mathrm{C}$ & $35^{\circ} \mathrm{C}$ & $42{ }^{\circ} \mathrm{C}$ & $49^{\circ} \mathrm{C}$ \\
\hline Day 4 & $85.07 \pm 5.60^{\mathrm{bA}}$ & $92.03 \pm 0.47 \mathrm{aA}$ & $91.76 \pm 0.31 \mathrm{aA}$ & $91.71 \pm 0.19 \mathrm{aA}$ \\
\hline Day 8 & $87.76 \pm 0.82^{\mathrm{bA}}$ & $92.09 \pm 0.19 \mathrm{aA}$ & $92.07 \pm 0.22 \mathrm{aA}$ & $91.61 \pm 0.29 \mathrm{aA}$ \\
\hline Day 12 & $87.87 \pm 0.29^{\mathrm{bA}}$ & $91.68 \pm 0.19$ aA & $91.95 \pm 0.15^{\mathrm{aA}}$ & $91.87 \pm 0.15 \mathrm{aA}$ \\
\hline Day 16 & $89.32 \pm 1.27^{\mathrm{bA}}$ & $91.38 \pm 0.15^{\mathrm{aA}}$ & $91.95 \pm 0.13^{\mathrm{aA}}$ & $91.64 \pm 0.43^{\mathrm{aA}}$ \\
\hline
\end{tabular}

$\overline{a-b}$ Means \pm standard error with different retting temperatures within the same row are significantly different $(p<0.05)$. $^{\mathrm{A}-\mathrm{B}}$ Means \pm standard error with different retting times within the same column are significantly different $(p<0.05)$

TOTAL PHENOLIC CONTENT OF WHITE PEPPER

For the total phenolic content (TPC), all temperatures employed produced significantly different $(p<0.05)$ amounts of TPC regardless of days of retting. Table 4 shows that the lowest TPC was obtained at $28{ }^{\circ} \mathrm{C}$ on day $4(12.21 \pm 0.40 \mathrm{mg} \mathrm{GAE} / \mathrm{g})$, followed by 42 and 49 ${ }^{\circ} \mathrm{C}$. The highest TPC was at $35{ }^{\circ} \mathrm{C}$ and day 4 (33.05 \pm $1.47 \mathrm{mg} \mathrm{GAE} / \mathrm{g}$ ) but was not significantly different from day 8. According to Lu et al. (2011), there is a strong relationship between phenolics concentration in spices and their free radical scavenging. Phenolic compounds in spices may be the major contributor to their antioxidant capacity. Zarai et al. (2013) reported the highest amount of total phenolics in black pepper ethanolic extracts gave a high antioxidant activity and was higher than BHT standard antioxidant. Similarly, the lower polyphenolics compound present at $28{ }^{\circ} \mathrm{C}$, day 4 retting resulted in a lower DPPH activity compared to another sample tested. Variyar and Bandyopadhyay (1994) earlier work reported syringic, vanillic, and ferulic acid in the phenolic acid fraction. Pepper also has been reported to contain 3,4-dihydroxyphenyl ethanol glucoside, 3,4-dihydroxy6-(N-ethylamino) benzamide, and phenolic acid glycosides as the main phenolic compounds (Chatterjee et al. 2007). Other than that, Agbor et al. (2006) explained that the effects of maturity or processing treatment may also reduce the polyphenol content in white pepper eventually.

TABLE 4. Values of the total phenolic content (mg GAE/g) of white pepper produced after the water retting process at different temperatures and days

\begin{tabular}{|c|c|c|c|c|}
\hline & $28^{\circ} \mathrm{C}$ & $35^{\circ} \mathrm{C}$ & $42{ }^{\circ} \mathrm{C}$ & $49^{\circ} \mathrm{C}$ \\
\hline Day 4 & $12.21 \pm 0.40^{\mathrm{d}} \mathrm{C}$ & $33.05 \pm 1.47^{\mathrm{aA}}$ & $28.23 \pm 1.06^{\mathrm{bA}}$ & $24.54 \pm 0.13^{\mathrm{cA}}$ \\
\hline Day 8 & $12.66 \pm 0.31^{\mathrm{cC}}$ & $32.95 \pm 0.18^{\mathrm{aA}}$ & $24.51 \pm 0.72^{\text {ьв }}$ & $23.99 \pm 0.82^{\mathrm{bA}}$ \\
\hline Day 12 & $14.80 \pm 0.15^{\mathrm{dA}}$ & $31.09 \pm 0.34^{\mathrm{aA}}$ & $27.57 \pm 0.37^{\mathrm{bA}}$ & $24.85 \pm 1.32^{\mathrm{cA}}$ \\
\hline Day 16 & $13.89 \pm 0.10 \mathrm{~dB}$ & $30.95 \pm 0.51 \mathrm{aA}$ & $27.43 \pm 0.43^{\mathrm{bA}}$ & $21.74 \pm 1.11^{\mathrm{cA}}$ \\
\hline
\end{tabular}

a-b Means \pm standard error with different retting temperatures within the same row are significantly different $(p<0.05)$. ${ }^{\text {A-B }}$ Means \pm standard error with different retting times within the same column are significantly different $(p<0.05)$ 


\section{PIPERINE CONTENT}

Table 5 shows the highest piperine content was obtained from white pepper retted at $35^{\circ} \mathrm{C}$ on day $8(2.70 \pm$ $0.25 \%$ ). The study shows that the piperine content in the Piperaceae family is different according to the species (Raman \& Gaikar 2002). In Piper nigrum L. fruit, the range of piperine is 2.0 to $7.4 \%$ (Peter 2006; Risfaheri \& Nurdjannah 2003) suggesting that the yield of piperine is within an acceptable range at temperatures of 28,35 , and 42 ${ }^{\circ} \mathrm{C}$. An increase in the retting period shows no effect at all temperatures except at $49^{\circ} \mathrm{C}$ with decreasing piperine as the retting time increased. Due to longer retting time, piperine was prone to be released and lost to the surrounding by the heat treatment. As for the temperature effect on day 8 and day 16 at a higher retting temperature $\left(49{ }^{\circ} \mathrm{C}\right)$, it caused the piperine content to reduce significantly. Another study showed that as the temperature increased when subjected to boiling or pressure cooking treatment, piperine content in Piper nigrum L. gradually decreased (Attokaran 2011; Meghwal \& Goswami 2013). The study of Dang and Phan (2014) showed a poor correlation $\left(R^{2}=0.32\right)$ of the piperine content with black pepper oleoresin yield. Extraction using supercritical $\mathrm{CO}_{2}$ at different pressures, temperatures, and durations were able to yield a higher range of piperine from 25.74 to $48.32 \%$. Piperine and piperic acid could be used as a natural antioxidant and antibacterial agents in both food preservation and human health (Zarai et al. 2013).

TABLE 5. Piperine content (\%) of white pepper produced after the water retting process at different temperatures and days

\begin{tabular}{|c|c|c|c|c|}
\hline & $28^{\circ} \mathrm{C}$ & $35^{\circ} \mathrm{C}$ & $42{ }^{\circ} \mathrm{C}$ & $49^{\circ} \mathrm{C}$ \\
\hline Day 4 & $1.76 \pm 0.08^{\mathrm{aA}}$ & $2.21 \pm 0.30^{\mathrm{aA}}$ & $2.10 \pm 0.09^{\mathrm{aA}}$ & $2.06 \pm 0.03 \mathrm{aA}$ \\
\hline Day 8 & $2.59 \pm 0.20 \mathrm{abA}$ & $2.70 \pm 0.25^{\mathrm{aA}}$ & $2.14 \pm 0.04^{\mathrm{bcA}}$ & $1.80 \pm 0.10^{\mathrm{cB}}$ \\
\hline Day 12 & $2.35 \pm 0.11 \mathrm{aA}$ & $1.97 \pm 0.28 \mathrm{aA}$ & $2.11 \pm 0.08^{\mathrm{aA}}$ & $1.92 \pm 0.00 \mathrm{aAB}$ \\
\hline Day 16 & $2.06 \pm 0.31^{\mathrm{aA}}$ & $1.81 \pm 0.27 \mathrm{abA}$ & $2.27 \pm 0.03^{\mathrm{aA}}$ & $1.54 \pm 0.13^{\mathrm{bC}}$ \\
\hline
\end{tabular}

${ }^{\mathrm{a}-\mathrm{b}}$ Means \pm standard error with different retting temperatures within the same row are significantly different $(p<0.05)$. $^{\mathrm{A}-\mathrm{B}}$ Means \pm standard error with different retting times within the same column are significantly different $(p<0.05)$

\section{CONCLUSION}

The study shows that the best solvent is methanol due to its ability to recover highest yield and total phenolic content of oleoresin extract. In addition, there are effects of temperature and day on the physicochemical and functional properties of white pepper produced, with the temperature factor being more pronounced on the properties tested. Retting temperature at $28^{\circ} \mathrm{C}$ and 8 days was sufficient to produce a significantly higher yield and most fractured white pepper. Meanwhile, white pepper retted at higher temperatures for 8 days was sufficient to produce better colour $\left(42^{\circ} \mathrm{C}\right)$ as well as the highest piperine content, highest free scavenging activity, and TPC value $\left(35^{\circ} \mathrm{C}\right)$.

\section{ACKNOWLEDGEMENTS}

The authors would like to thank the Ministry of Education Malaysia for funding this project under research grant
FRGS/1/2016/WAB01/UKM/02/2 and the Department of Food Sciences, Faculty of Science and Technology, Universiti Kebangsaan Malaysia for providing the research facilities.

\section{REFERENCES}

Agbor, G.A., Vinson, J.A., Oben, J.E. \& Ngogang, J.Y. 2006. Comparative analysis of the in vitro antioxidant activity of white and black pepper. Nutrition Research 26(12): 659-663.

Akin, D.E. 2010. Flax - structure, chemistry, retting and processing. In Industrial Applications of Natural Fibres: Structure, Properties and Technical Applications, edited by Mussig, I.J. London: John Wiley \& Sons. pp. 89-96.

Andrade, K.S. \& Ferreira, S.R.S. 2013. Antioxidant activity of black pepper (Piper nigrum L.) oil obtained by super critical $\mathrm{CO}_{2}$. University of Santa Catarina, Ph.D. Thesis (Unpublished).

Attokaran, M. 2011. Black Pepper. In Natural Food Flavors and Colorants, edited by Wiley, B. $2^{\text {nd }}$ ed. Oxford: Blackwell Publishing. pp. 87-93. 
Aziz, N.S., Sofian-Seng, N.S., Mohd Razali, N.S., Lim, S.J. \& Wan Mustapha, W.A. 2019. A review on conventional and biotechnological approaches in white pepper production. Journal of the Science of Food and Agriculture 99(6): 2665-2676.

Aziz, N.S., Sofian-Seng, N.S. \& Wan Mustapha, W.A. 2018. Functional properties of oleoresin extracted from white pepper (Piper nigrum L.) retting waste water. Sains Malaysiana 47(9): 2009-2015.

Balasubramanian, S., Roselin, P., Singh, K.K., Zachariah, J. \& Saxena, S.N. 2016. Postharvest processing and benefits of black pepper, coriander, cinnamon, fenugreek, and turmeric spices. Critical Reviews in Food Science and Nutrition 56(10): 1585-1607.

Borges, P. \& Pino, J. 1993. Preparation of black pepper oleoresin by alcohol extraction. Food/Nahrung 37(2): 127-130.

Butsat, S. \& Siriamornpun, S. 2016. Effect of solvent types and extraction times on phenolic and flavonoid contents and antioxidant activity in leaf extracts of Amomum chinense C. International Food Research Journal 23(1): 180-187.

Chatterjee, S., Niaz, Z., Gautam, S., Adhikari, S., Variyar, P.S. \& Sharma, A. 2007. Antioxidant activity of some phenolic constituents from green pepper (Piper nigrum L.) and fresh nutmeg mace (Myristica fragrans). Food Chemistry 101(2): 515-523.

Choi, B.M., Kim, S.M., Park, T.K., Li, G., Hong, S.J., Park, R., Chung, H.T. \& Kim, B.R. 2007. Piperine protects cisplatininduced apoptosis via heme oxygenase-1 induction in auditory cells. The Journal of Nutritional Biochemistry 18(9): 615-622.

Dang, Q.T. \& Phan, N.N. 2014. Optimization of supercritical $\mathrm{CO}_{2}$ extraction of oleoresin from black pepper (Piper nigrum L.) and antioxidant capacity of the oleoresin. International Food Research Journal 21(4): 1489-1493.

Dutta, P.C. 2003. Phytosterols as Functional Food Components and Nutraceuticals. New York: Taylor \& Francis.

Esmaeili, A.K., Taha, R.M., Mohajer, S. \& Banisalam, B. 2016. In vitro regeneration and comparison of phenolic content, antioxidant and antityrosinase activity of in vivo and in vitro grown Asparagus officinalis. Sains Malaysiana 45(3): 373-381.

Gámiz-Gracia, L. \& Luque de Castro, M.D. 2000. Continuous subcritical water extraction of medicinal plant essential oil: Comparison with conventional techniques. Talanta 51(6): 1179-1185.

Gorgani, L., Mohammadi, M., Najafpour, G.D. \& Nikzad, M. 2017. Piperine-the bioactive compound of black pepper: From isolation to medicinal formulations. Comprehensive Reviews in Food Science and Food Safety 16: 1-17.

Goss, J.A. 2013. Physiology of Plants and Their Cells: Pergamon Biological Sciences Series. (Vol. 1). New York: Elsevier.

Hamrapurkar, P.D., Jadhav, K. \& Zine, S. 2011. Quantitative estimation of piperine in Piper nigrum and Piper longum using high performance thin layer chromatography. Journal of Applied Pharmaceutical Science 1(3): 117-120.

Hassas Roudsari, M. 2007. Subcritical water extraction of antioxidant compounds from canola meal. University of Saskatchewan. Ph.D. Thesis (Unpublished).
Hatami, T., Emami, S.A., Miraghaee, S.S. \& Mojarrab, M. 2014. Total phenolic contents and antioxidant activities of different extracts and fractions from the aerial parts of Artemisia biennis Willd. Iranian Journal of Pharmaceutical Research 13(2): 551-559.

Ibrahim, M.D., Iskandar, N.A.N.R., Ashaari, M.F., Zulkharnain, A. \& Hussaini, A.A.S.A. 2014. Durable hybrid-powered white pepper retting machine integrated with crude enzymatic solution. Journal of Applied Science and Agriculture 9(15): 6-13.

Jiménez-Carmona, M.M., Ubera, J.L. \& Luque de Castro, M.D. 1999. Comparison of continuous subcritical water extraction and hydrodistillation of marjoram essential oil. Journal of Chromatography A 855(2): 625-632.

Kanaki, N., Dave, M., Padh, H. \& Rajani, M. 2008. A rapid method for isolation of piperine from the fruits of P. nigrum Linn. Journal of Natural Medicines 6: 281-283.

Karaman, S., Tütem, E., Başkan, K.S. \& Apak, R. 2010 Comparison of total antioxidant capacity and phenolic composition of some apple juices with combined HPLCCUPRAC assay. Food Chemistry 120(4): 1201-1209.

Kolhe, S.R., Borole, P. \& Patel, U. 2011. Extraction and evaluation of piperine from Piper nigrum Linn. International Journal of Applied Biology and Pharmaceutical Technology 2(2): 144-149.

Lenucci, M.S., De Caroli, M., Marrese, P.P., Iurlaro, A., Rescio, L., Böhm, V., Dalessandro, G. \& Piro, G. 2015. Enzyme-aided extraction of lycopene from high-pigment tomato cultivars by supercritical carbon dioxide. Food Chemistry 170: 193-202.

Lu, M., Yuan, B., Zeng, M. \& Chen, J. 2011. Antioxidant capacity and major phenolic compounds of spices commonly consumed in China. Food Research International 44(2): 530-536.

Marion, L. 1960. The pyrrolidine alkaloids. In The Alkaloids Chemistry and Physiology. London: Academic Press. pp. 31-34.

Meghwal, M. \& Goswami, T.K. 2013. Piper nigrum and piperine: An update. Phytotherapy Research 27(8): 1121-1130.

Meullemiestre, A., Breil, C., Abert-Vian, M. \& Chemat, F. 2015. Modern Techniques and Solvents for the Extraction of Microbial Oils. New York: Springer International Publishing.

Misharina, T.A., Terenina, M.B. \& Krikunova, N.I. 2009. Antioxidant properties of essential oils. Applied Biochemistry and Microbiology 45(6): 710-716.

Mothersill, C. \& Austin, B. 2003. In Vitro Methods in Aquatic Ecotoxicology. UK: Springer.

Nair, K.P.P. 2011. Agronomy and Economy of Black Pepper and Cardamom: The "King" and "Queen" of Spices. London: Elsevier.

Nurhanan, A.R., Wan Rosli, W.I. \& Mohsin, S.S. 2012. Total polyphenol content and free radical scavenging activity of cornsilk (Zea mays hairs). Sains Malaysiana 41(10): 12171221.

Parthasarathy, V.A., Chempakam, B. \& Zachariah, T.J. 2008. Chemistry of Spices. UK: Centre for Agriculture and Bioscience International (CABI). 
Paulus, A.D. 2009. Harvesting, processing, drying and storage of pepper. Universiti Putra Malaysia (UPM).

Peter, K.V. 2006. Handbook of Herbs and Spices. New York: CRC Press.

Premi, B.R. 2000. Essential oils and oleoresins in India. Beverage and Food World 27(4): 12-19.

Prytula, M. \& Pavolostathis, S. 1996. Extraction of sedimentbound chlorinated organic compounds: Implications on fate and hazard assesment. Water Science and Technology 33: 247-254.

Qi, X., Chen, X. \& Wang, Y. 2014. Plant Metabolomics: Methods and Applications. Netherlands: Springer.

Raman, G. \& Gaikar, V. 2002. Microwave-assisted extraction of piperine from Piper nigrum. Industrial \& Engineering Chemistry Research 41: 2521-2528.

Ramawat, K.G. \& Ahuja, M.R. 2016. Fiber Plants: Biology, Biotechnology and Applications. (Vol. 13). Switzerland: Springer.

Ravindran, P.N. 2003. Black Pepper: Piper nigrum Medicinal and Aromatic Plants - Industrial Profiles. Amsterdam: Harwood Acedemic Publisher.

Ravindran, P.N. \& Kallupurackal, J.A. 2012. Black pepper. In Handbook of Herbs and Spices. Cambridge UK: Woodhead Publishing Limited. pp. 87-115.

Ravindran, P.N. \& Kallupurackal, J.A. 2001. Black pepper. In Handbook of Herbs and Spices. United Kingdom: Woodhead Publishing Limited. pp. 62-110.

Risfaheri \& Nurdjannah, N. 2003. Pepper processing- the Indonesian scenario. In Black Pepper: Piper nigrum Medicinal and Aromatic Plants - Industrial Profiles, edited by Ravindran, P.N. Netherlands: Harwood Acedemic Publisher. pp. 365-377.

Rosnah, S. \& Chan, S.C. 2014. Enzymatic rettings of green pepper berries for white pepper production. International Food Research Journal 21(1): 237-245.

Sadasivam, S. \& Manickam, A. 1992. Biochemical Methods for Agricultural Sciences. Madras: Wiley Eastern Ltd.

Samaj, J. \& Thelen, J.J. 2007. Plant Proteomics. Berlin, New York: Springer.

Santamaría, R.I., Reyes-Duarte, M.D., Bárzana, E., Fernando, D., Gama, F.M., Mota, M. \& López-Munguía, A. 2000. Selective enzyme-mediated extraction of capsaicinoids and carotenoids from chili guajillo puya (Capsicum annuum L.) using ethanol as solvent. Journal of Agricultural and Food Chemistry 48(7): 3063-3067.

Schweiggert, U., Carle, R. \& Schieber, A. 2007. Conventional and alternative processes for spice production - A review. Trends in Food Science \& Technology 18(5): 260-268.

Shaikh, J., Bhosale, R. \& Singhal, R. 2006. Microencapsulation of black pepper oleoresin. Food Chemistry 94(1): 105-110.

Shanmugapriya, K., Saravana, P.S., Payal, H., Peer Mohammed, S. \& Williams, B. 2012. Antioxidant potential of pepper (Piper nigrum Linn.) leaves and its antimicrobial potential against some pathogenic microbes. Indian Journal of Natural Products and Resources 3(4): 570-577.

Shingate, P.N., Dongre, P.P. \& Kannur, D.M. 2013. New method development for extraction and isolation of piperine.
International Journal of Pharmaceutical Sciences and Research 4(8): 3165-3170.

Singh, S., Kapoor, I.P.S., Singh, G., Schuff, C., De Lampasona, M.P. \& Catalan, C.A. 2013. Chemistry, antioxidant and antimicrobial potentials of white pepper (Piper nigrum L.) essential oil and oleoresins. Proceedings of the National Academy of Sciences, India Section B: Biological Sciences 83(3): 357-366.

Sons, J.W., Kirk, R.E., Othmer, D.F. \& Seidel, A. 2007. KirkOthmer Food and Feed Technology. New York: Wiley.

Soto Ayala, R. \& Luque de Castro, M.D. 2001. Continuous subcritical water extraction as a useful tool for isolation of edible essential oils. Food Chemistry 75(1): 109-113.

Srinivasan, K. 2007. Black pepper and its pungent principlepiperine: A review of diverse physiological effects. Critical Reviews in Food Science and Nutrition 47(8): 735-748.

Sruthi, D., Zachariah, T.J., Leela, N.K. \& Jayarajan, K. 2013. Correlation between chemical profiles of black pepper (Piper nigrum L.) var. Panniyur-1 collected from different locations. Journal of Medicinal Plants Research 7(31): 2349-2357.

Steinhaus, M. \& Schieberle, P. 2005. Characterization of odorants causing an atypical aroma in white pepper powder (Piper nigrum L.) based on quantitative measurements and orthonasal breakthrough thresholds. Journal of Agricultural and Food Chemistry 53(15): 6049-6055.

Subramanian, R., Subbramaniyan, P., Ameen, J.N. \& Raj, V. 2016. Double bypasses soxhlet apparatus for extraction of piperine from Piper nigrum. Arabian Journal of Chemistry 9: 537-540.

Tahir, M.P., Ahmed, B.A., SaifulAzry, S.O.A. \& Ahmed, Z. 2011. Retting process of some bast plant fibres and its effect on fibre quality: A review. BioResources 6(4): 5260-5281.

Tainter, D.R. \& Grenis, A.T. 2001. Spices and Seasonings. New York: Wiley.

Upadhyay, V., Sharma, N., Joshi, H.M., Malik, A., Mishra, M., Singh, B.P. \& Tripathi, S. 2013. Development and validation of rapid RP-HPLC method for estimation of piperine in Piper nigrum L. International Journal of Herbal Medicine 1(4): 6-9.

Variyar, P.S. \& Bandyopadhyay, C. 1994. Estimation of phenolic compounds in green pepper berries (Piper nigrum L.) by high-performance liquid chromatography. Chromatographia 39(11-12): 743-746.

Vinod, V., Kumar, A. \& Zachariah, T.J. 2014. Isolation, characterization and identification of pericarp-degrading bacteria for the production of off odour free white pepper from fresh berries of Piper nigrum L. Journal of Applied Microbiology 116(4): 890-902.

Wern, K.H., Haron, H. \& Keng, C.B. 2016. Comparison of total phenolic contents (TPC) and antioxidant activities of fresh fruit juices, commercial 100\% fruit juices and fruit drinks. Sains Malaysiana 45(9): 1319-1327.

Zachariah, J. 2008. Report of Production of White Pepper Through Fermentation Technology. Indian Institute of Spices Research (ICAR).

Zarai, Z., Boujelbene, E., Salem, N.B., Gargouri, Y. \& Sayari, A. 2013. Antioxidant and antimicrobial activities of various 
solvent extracts, piperine and piperic acid from Piper nigrum. LWT-Food Science and Technology 50(2): 634-641.

Nurul Shahirah Aziz, Noor-Soffalina Sofian-Seng \& Wan Aida Wan Mustapha*

Department of Food Sciences

Faculty Science and Technology

Universiti Kebangsaan Malaysia

43600 UKM Bangi, Selangor Darul Ehsan

Malaysia
Noor-Soffalina Sofian-Seng \& Wan Aida Wan Mustapha* Innovation Centre for Confectionery Technology (MANIS) Faculty of Science and Technology

Universiti Kebangsaan Malaysia

43600 UKM Bangi, Selangor Darul Ehsan

Malaysia

*Corresponding author; email: wanaidawm@ukm.edu.my

Received: 16 January 2020

Accepted: 17 August 2020 